\title{
Radiation Effects on Insulators for Superconducting Magnets
}

\author{
R. H. Kernohan \\ R. R. Coltman, Jr. \\ C. J. Long
}




\section{DISCLAIMER}

This report was prepared as an account of work sponsored by an agency of the United States Government. Neither the United States Government nor any agency Thereof, nor any of their employees, makes any warranty, express or implied, or assumes any legal liability or responsibility for the accuracy, completeness, or usefulness of any information, apparatus, product, or process disclosed, or represents that its use would not infringe privately owned rights. Reference herein to any specific commercial product, process, or service by trade name, trademark, manufacturer, or otherwise does not necessarily constitute or imply its endorsement, recommendation, or favoring by the United States Government or any agency thereof. The views and opinions of authors expressed herein do not necessarily state or reflect those of the United States Government or any agency thereof. 


\section{DISCLAIMER}

Portions of this document may be illegible in electronic image products. Images are produced from the best available original document. 


\section{Printed in the United States of America. Available from National Tcchnical Information Service \\ U.S. Department of Commerce \\ 5285 Port Royal Road, Springfield, Virginia 22161 \\ Price: Printed Copy $\$ 4.50$; Microfiche $\$ 3.00$}

This report was prepared as an account of work sponsored by an agency of the United States Government. Neither the United States Government nor any agency thereof, nor any of their employees, contractors, subcontractors, or their employees, makes any warranty, express or implied, nor assumes any legal liability or responsibility for any third party's use or the results of such use of any information, apparatus, product or process disclosed in this report, nor represents that its use by such third party would not infringe privately owned rights. 
Contract No. W-7405-eng-26

SOLID STATE DIVISION

RADIATION EFFECTS ON INSULATORS FOR SUPERCONDUCTING MAGNETS

R. H. Kernohan, R. R. Coltman, Jr., C. J. Long*

*Melals and Ceramics Division.

Date Published: January 1978

NOTICE This document contains information of a preliminary nature. It is subject to revision or correction and therefore does not represent a final roport.

\author{
OAK RIDGE NATIONAL LABORATORY \\ Oak Ridge, Tennessee 37830 \\ Operated by \\ UNION CARBIDE CORPORATION \\ for \\ DEPARTMENT OF ENERGY
}


THIS PAGE

\section{WAS INTENTIONALLY LEFT BLANK}


CONTENTS

Page

Abstract $\ldots \ldots \ldots \ldots \ldots \ldots \ldots \ldots \ldots \ldots \ldots \ldots \ldots \ldots \ldots \ldots \ldots$

I. Introduction $\ldots \ldots \ldots \ldots \ldots \ldots \ldots \ldots \ldots \ldots \ldots \ldots \ldots \ldots$

II. Irradiation Facility $\ldots \ldots \ldots \ldots \ldots \ldots \ldots \ldots \ldots$

III. Specimen Fabrication and Tests ........... 4

IV. Materials $\ldots \ldots \ldots \ldots \ldots \ldots \ldots \ldots \ldots \ldots \ldots \ldots \ldots$

V. Experiment Design $\ldots \ldots \ldots \ldots \ldots \ldots \ldots \ldots \ldots \ldots$

VI. Irradiation Schedule $\ldots \ldots \ldots \ldots \ldots \ldots \ldots \ldots \ldots, 12$

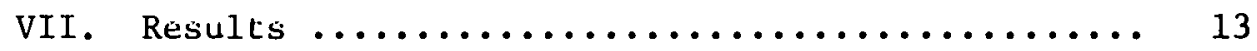

VIII. Conclusions and Future Plans ............ 17

IX. Acknowledgments $\ldots \ldots \ldots \ldots \ldots \ldots \ldots \ldots \ldots \ldots \ldots$

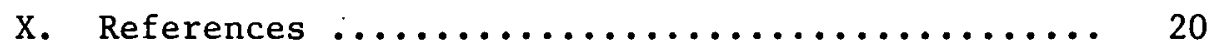


RADIATION EFFECTS ON INSULATORS FOR SUPERCONDUCTING MAGNETS

R. H. Kernohan, R. R. Coltman, Jr., C. J. Long ${ }^{\dagger}$ Solid State Division, Oak Ridge National Laboratory

Oak Ridge, Tennessee

\section{ABSTRACT}

In order to determine the radiation stability of electrical insulation that could be used in a superconducting magnet for containment of the plasma in a fusion energy device, 55 specimens of eight types of organic insulation were irradiated to a dose of about $2 \times 10^{8} \mathrm{R}\left(2 \times 10^{6}\right.$ $\mathrm{J} / \mathrm{Kg}$ ) at a temperature of $4.8 \mathrm{~K}$ in the Low-Temperature Irradiation Facility in the Bulk Shielding Reactor at Oak Ridge National Laboratory. Four of the specimens were monitored for changes in electrical resistivity during the irradiation. The initial resistivities, which were of the order of $10^{14} \Omega \mathrm{cm}$, decreased to about $10^{13} \Omega \mathrm{cm}$ under the influence of a weak radiation field. At full-power reactor operation (2 MW), the resistivities dropped to about $10^{11} \Omega \mathrm{cm}$, but changed little during the irradiation. After the irradiation the resistivities increased, but not to the initial values, because of residual radioactivity near or in the experiment assembly. Restoration to near the initial resistivity values was later observed upon warming the specimens to room temperature and purging the irradiation chamber. The latter result may be related to outgassing induced by the irradiation.

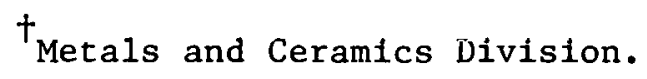


RADIATION EFFECTS ON INSULATORS FOR SUPERCONDUCTING MAGNETS

R. H. Kernohan, R. R. Coltman, Jr., and C. J. Long

\section{INTRODUCTION}

The containment of reacting plasmas in fusion-energy devices appears possible only with the use of high magnetic fields. Such fields can be produced economically by the use of large superconducting magnets which operate at liquid-helium temperature.

It is well known that the first wall nearest the plasma will operate at extremely high temperatures and under intense irradiation from nuclear reactions. However, an intervening energy-absorption blanket and radiation shield between the plasma and magnet should make it possible to operate a large-diameter magnet at 1iquid-helium temperatures. To achieve economic magnet operation, however, the attenuation in the blanket and shield must be large. Detalled final designs do not exist at this time either for fusion-power reactors or for their component parts, such as blanket, shịeld, and magnets.

Some present estimates indicate that the average radiation to be expected at the front surface of the magnet system would be of the order of $10^{7} \mathrm{R} / \mathrm{yr}\left(10^{5} \mathrm{~J} / \mathrm{Kg} / \mathrm{yr}\right)$. The lifetime of the magnet would be approximately 20 years, resulting in a radiation dose of $2 \times 10^{\vee} \mathrm{K}$. 'l'he energydeposition rate at the front face of the magnet system would be on the order of $1 \mathrm{~mW} / \mathrm{K}_{\mathrm{g}}$.

A literature survey on the effects of radiation on materials of possible interest to superconducting-magnet designers has been made. (1) 
From all indications, structural metals and superconductors are expected to withstand the anticipated dose, particularly if there are intermittent anneals to room temperature during the operating lifetime. However, by contrast, very little information about the low-temperature-irradiation behavior of organic insulating materials is available in the literature. If changes are found to occur, such information is vital to magnet design. Many organic materials irradiated at room temperature to dose levels expected in the magnets begin to show a degradation in physical properties. (2) This is the reason for the present investigation of insulating materials under the simultaneous conditions of low temperature and irradiation.

\section{IRRADIATION FACILITY}

The Low-Temperature Irradiation Facility (LTIF) located in the Bulk Shielding Reactor (BSR) at ORNL enables one to simulate the lifetime dose expected in the magnets of proposed operating fusion devices in a matter of several hours of irradiation.

The access tube to the sample chamber of the LTIF is a straight vertical tube $2.5 \mathrm{~cm}$ in diameter $\times 5.7 \mathrm{~m}$ extending from just above the BSR pool water surface down to the $20-\mathrm{cm}-1$ long sample chamber as shown in Fig. 1. The sample chamber is the refrigerated cold zone where irradiations are performed. The walls of the cold zone are cooled on the outside by process liquid helium supplied by a continuously operating, closed-cycle refrigerator-1iquefier system described elsewhere. (3) The sample chamber, associated refrigeration transfer lines, and vacuum jacketing are located in a. 15-cm-diameter housing pipe which is surrounded by an aluminum tank 
filled with $\mathrm{D}_{2} \mathrm{O}$ to the level of the top of the reactor core. Th1s arrangement provides about $45 \mathrm{~cm}$ of heavy-water moderator between the reactor face and the sample chamber. Anneallng studies at temperatures between 3.5 and $300 \mathrm{~K}$ can be made by adjusting refrigeration circuit flow rates. The reactor may be operated at any power level from about $50 \mathrm{~W}$ to $2 \mathrm{MW}$. The reactor core can be detached from the LTIF and moved two or three meters away in the BSR pool water. The thermal neutron flux in the I.M. with the reactor at full power (2 MW) is $2.5 \times 10^{12} \mathrm{n} / \mathrm{cm}^{2} / \mathrm{sec}$, while the fast flux (> $3 \mathrm{MeV})$ is $9 \times 10^{\circ} \mathrm{n} / \mathrm{cm}^{2} / \mathrm{sec}$. The gamma-ray heating is about $20 \mathrm{~mW} / \mathrm{g}$, which indicates a dose rate of about $7 \times 10^{6} \mathrm{R} / \mathrm{h}$. Some experiment assemblies, including the one used in this experiment, are surrounded by a cadmium shield. This greatly attenuates the thermal-neutron flux and reduces the radioactivity of the samples, but affects the fast-neutron flux very little. The cadmium shield also increases the gamma-ray intensity. A recent test with a cadmium-shield configuration nearly identical to the one used in this experiment shows gamma-ray heating to be $38 \mathrm{~mW} / \mathrm{g}$, corresponding to a dose rate of $1.4 \times 10^{7}$ $\mathrm{R} / \mathrm{h}$.

\section{SPECIMEN FABRICATTON AND TESTS}

The dimensions of the LTIF make it necessary to consider sub-size specimens for irradiation testing. Therefore, standard specimen designs were scaled down to fit the available space. Two electrical tests, elecLriçal resistance and voltage breakdown, and two mechanical tests, flexure and lap-shear (tensile-shear) were selected. The specific tests performed on each material were chosen to measure those properties important 
to its particular use in a magnet. Electrical-resistance measurements were made on a few specimens in situ during the irradiation, and the results are given in this report. After decay of all radioactivity to a safe handling level, other specimens will be tested along with similar unirradiated control specimens. These postirradiation tests to be reported later will be performed at room temperature. The desirability of conducting such tests in liquid helium is recognized and is being considered for later experiments.

For the dc electrical-resistance test, the method given by the American Society for Testing and Materials (ASTM), D257-76, (4) was adapted to use specimens $1.25 \mathrm{~cm}$ in diameter. The specimen is a circular sandwich with an electrode covering one side, the insulator in the middle, and a central electrode with a concentric guard ring at the same potential on the other side. A molding device for making six specimens at a time from epoxy compounds, using copper-disk electrodes and guard rings, is shown in the upper right of Fig. 2. Also shown is a $1.25-\mathrm{cm}$ circular punch for making specimens from preformed film or sheet. The electrodes and guard rings for the latter were painted by hand on the thin disks, using electrically conducting silver-epoxy paint. Typical specimens of both types are shown in Fig. 3.

A testing device was designed and built to measure the resistance of the specimens. A battery power supply was constructed, and a picoammeter was adapted to measure currents through the insulation. This equipment is shown in Fig. 4. Because of the substandard specimen diameter, the specimen resistance values are relatively large. As a result 
the parallel leakage resistance of the attaching coaxial cables, especially the longer cables used in the radiation experiment assembly, placed an upper limit of about $10^{14} \Omega \mathrm{cm}$ on the specimen resistivity that could be measured. This value was felt to be well above that.needed for insulating material to be used in an operating magnet.

Equipment for measuring the voltage breakdown of transformer oils as described in the ASTM standard, (5) D877-67, is available at ORNL. It was found possible to revise the electrodes of this equipment so that small, thin specimens could be tested in the absence of oil. For this purpose, thin specimens $1.88 \mathrm{~cm}$ in diameter were fabricated by either casting epoxies into a mold or stamping out solid pieces with a circular punch. These fabricating devices are shown at the upper left in Fig. 2, and typical specimens are shown in Fig. 5.

The flexure-test specimens machined from solid materials were about $5 \mathrm{~cm}$ long, $0.3 \mathrm{~cm}$ wide, and $0.15 \mathrm{~cm}$ thick. Flexure specimens molded. from epoxy compounds were made six-at-a-time in the mold shown in the lower left of Fig. 2. The specimen will be tested using a 3-point suspension system in a standard mechanical testing machine.

Lap-shear (tensile-shear) specimens were tabricated trom epoxy materials using the mold shown in the lower right of. Fig. 2. The specimens were designed so that the hardened $\mathrm{Cu}-\mathrm{Be}$ pull tabs shown on the finished specimens in Fig. 6 nest together to minimize space. The epoxy materials take up the space at the joint where the three metal tabs come together. Each specimen is about $3.2 \mathrm{~cm}$ long. A special mounting $j \mathrm{fg}$ for attaching these specimens to a standard test machine was designed and fabricated. 
After fabrication, all specimens were immersed in liquid helium at least twice to insure that thermal shock would cause no deleterious effects. After fabrication, the specimens were stored in a dessicator. All specimens were photographed, checked for dimensions, weighed on an analytical balance, and, where possible, marked for identification before irradiation.

\section{MATERIALS}

The criteria for the choices made for the materials tested in this experiment were the following.

(1) Compatibility. Since the magnet coils are metallic and must be : dimensionally stable, the insulating materials must be chemically compatible with metals such as copper, stainless stee1, and aluminum; and it is desirable that coefficients of expansion should match. Most organic materials have coefficients much larger than metals. These coefficients can be reduced and made to match those of metals by the use of fillers, such as glass fiber, glass rovings, or $\mathrm{Al}_{2} \mathrm{O}_{3}$ or $\mathrm{SiO}_{2}$ powders.

(2) Previous radiation results. Much research has already been done on plastics irradiated at room temperature. $(2,6,7)$ Those unsuitable under room-temperature irradiation conditions, such as Teflon and cellulose fiber compusites, can probably be eliminated from consideration. Those materials with fillers tend to show greater resistance to radiation than pure organic compounds. Also, as a general rule, those materials that withstand high temperatures appear to be more resistant to radiation effects than others. 
(3) Avallability. In most cases, it was deemed wiser to select materlals already on the market than to fabricate organic materials locally. However; this decision prevents exact characterization of materials, because such information is of ten proprietary.

(4) Formability. Materials to be used in the magnet should be easy to make, form, and apply. For example, epoxies that require a long time or high temperatures to cure would not be as suitable as others that would harden in a few hours at or near room temperature.

(5) Previous tests. A number of epoxy combinations had been tested for mechanical strength and shear strength at liquid-nitrogen temperature but without radiation. ( 8$)$ The best of these materials were considered. Also, experimenters who have worked in cryogenics for many years have discovered several plastics and epoxies that are most suitable.

The materials selected for specimen fabrication were the following.

(1) Stycast 2850 FT Blue epoxy with $7 \% 24 \mathrm{LV}$ hardener, manufactured by Emerson and Cuming, Inc. 'lhis is a filled epoxy (inorganic filler) suitable for insulation at higher voltages. It has been used successfully at cryogenic temperatures for joining metals. It hardens at room temperature in 16 - 24 hours.

(2) EPON 828 epoxy with $70 \%$ EPON 871 flexibilizer and 13 pph of 2 curing agent, manufactured by Shell Chemical Company. No filler was admixed, but $0.5 \%$ of $\mathrm{z} 6020$ Silane coupling agent was added. This formulation has exhibited excellent strength when tested at liquid-nitrogen temperature, ${ }^{(8)}$ but has the disadvantage that it must be cured at $68 \mathrm{C}$ for 24 hours.

(3) B-stage glass cloth, EF 527, manufactured by Synthane Taylor. It 
contains about $55 \%$ glass cloth by weight between layers of partially cured epoxy resin. It has exhibited good strength qualities at liquid-nitrogen temperatures, but requires curing at $175 \mathrm{C}$ for 2 hrs. under pressure.

(4) Glass-epoxy high-pressure laminate meeting National Electrical Manufacturers Association (NEMA) specification G-10. (9)

(5) Glass-epoxy high-pressure laminate meeting NEMA specification FR-5. (9) Similar to G-10, but with resin chosen for service at higher temperatures and for flame resistance. It is "Fireban 1011," manufactured by Synthane-Taylor Company.

(6) Nomex Aramid, type 410. It is an aromatic polyamide sheet material with excellent electrical properties, manufactured by Du Pont.

(7) Kapton polyimide film material, manufactured by Du Pont. It is reported to have excellent thermal and electrical properties and has frequently been used in cryogenic magnets.

In addition, a $25 \mu \mathrm{m}(1 \mathrm{mil})$ thick $\times 2.5 \mathrm{~cm}$ square piece of aluminized mylar, such as is often used as super-insulation, was irradiated. No specific tests except general appearance and weight change will be conducted on this specimen.

In general, three similar specimens for each test were irradiated, and three similar control specimens were held aside for comparison. These control specimens were subjected to the same temperature cycling as the irradiated specimens. 


\section{EXPERIMENT DESIGN}

Previous experience with the LTIF Indicated that electricalresistance measurements are the easiest type to make in situ during irradiation, and for this reason they were selected for the first survey experiment. However, electrical resistance measurements on insulators using the equipment described above require that stray currents be kept to a minimum, and it was recognized that such measurements made remotely on small specimens would have limited sensitivity. The upper half of the $2.5 \mathrm{~cm} \times 20 \mathrm{~cm}$ irradiation space was devoted to electrical resistance measurements made in situ during irradiation and the lower half to specimens for postirradiation testing.

The specimen container was a cylinder of cadmium foil $2.4 \mathrm{~cm}$ in diameter, $18.7 \mathrm{~cm}$ long with a $0.25-\mathrm{mm}$ wall, having end caps made of fired lavite ceramic. The container without the cadmium cylinder is shown in Fig. 7 with four resistance specimens in place in the upper half. A central stainless-steel support tube extends from the top lavite piece $5.56 \mathrm{~m}$ to a brass vacuum-sealing flange at the top of the assembly. This tube also serves as the positive voltage lead (or ground) for electrical measurements. A smaller stainless-steel rod soldered to the support tube is shaped to accommodate the in situ specimens and to support the two lower. lavite ceramic disks (see Fig. 7). Four copper lugs are soldered on this rod to serve as supports for the specimens shown in the upper half of Fig. 7. The bottom electrode of each specimen is fastened to each support with conducting epoxy cement.

To minimize leakage current, it is necessary to use coaxial cable to connect to the electrode and guard ring on the top of each specimen. 
While the radiation is at a maximum at the specimen container, some radiation is expected at 1 or 2 meters from the container; therefore, commercial coaxial cable with rubber and plastic insulation could not be used reliably in this region. Improvised coaxial conductors made of thin-wall stainless-steel tubing containing pure alumina thermocouple insulation tubing are used in the reduced radiation region above the experimental section. Magnet wire (No. 32 B \& S, Formvar-coated), $0.20 \mathrm{~mm}$ diameter, inside the alumina tubing served as the central conductor. Six of these thin-walled stainless-steel tubes placed radially around the central support tube extend about $1.5 \mathrm{~m}$ above the top of the upper lavite end cap. These are visible at the top of Fig. 7. The six tubes and the central support tube are isolated from each other with lavite spacer disks placed about $20 \mathrm{~cm}$ apart along the nest of tubes. At the top of each tube, about $4 \mathrm{~m}$ of commercial low-noise coaxial cable is connected, and these cables lead to a Plexiglas flange containing standard vacuum feed-throughs. The Plexiglas flange mates with a vacuum seal to a specially constructed brass elbow piece, so that the entire sample-access tube and chamber shown in Fig. 1 can be evacuated or filled with helium gas as desired.

In the top of the specimen container, No. 32 Formvar-insulated copper wires connect the outside of the coaxial tubes to the guard rings and connect the center wires to the top electrodes on the specimens. Porcelain thermocouple tubing, visible in Fig. 7, covers some of the longer lead wires. One of the coaxial tubes serves as a "dummy," or control; i.e., the leads were left open. At the end of another coaxial tube, the center lead wire and the tube lead wire (both Formvar-coated copper) are twisted together over a $2-\mathrm{cm}$ length. 
A copper-constantan thermocouple is installed in the specimen container, with its junction at the center lavite spaces in Fig. 7. This thermocouple permits temperature measurements above about $20 \mathrm{~K}$. Measurements of low temperatures are made by monitoring the vapor pressure above the liquid helium covering the specimens in the sample chamber.

\section{IRRADIATION SCHEDULE}

After the experiment assembly was lnaded Into the LTIF, the sample chamber was purged with dry helium gas and evacuated to about 0.1 torr (1 torr $=133 \mathrm{~Pa})$ pressure several times before initial cool-down.

Whenever possible, all in situ resistance measurements were made at a helium pressure of about one-half atmosphere or 150 torr at a potential of 90 volts. Currents in all six circuits were measured at room temperature and at about $100 \mathrm{~K}, 50 \mathrm{~K}$, and $4 \mathrm{~K}$ during cool-down before bringing the reactor to the LTIF position for irradiation.

With the specimen at $h .4 \mathrm{~K}$, current measurements were taken with the reactor at the following power levels: zero, * $50 \mathrm{~W}, 500 \mathrm{~W}, 5 \mathrm{KW}$, $50 \mathrm{KW}$, and $2 \mathrm{MW}$. The lowest power steps (zero and $50 \mathrm{~W}$ ) could possibly provide information on the resistance changes that might be expected in insulation at radiation dose rates at the magnet in an operating fusion reacior (* $1000 \mathrm{R} / \mathrm{h}$ ).

The irradiation at $2 \mathrm{MW}$ was interrupted after $1.5 \mathrm{~h}$, and the reactor was moved away from the LTIF. Resistance measurements were made at

\footnotetext{
*At zero power level the residual radioactivity of the reactor produces significant ionizing radiation.
} 
$4 \mathrm{~K}$ and step-annealing procedures carried out with steps at $50 \mathrm{~K}, 100 \mathrm{~K}$, and $300 \mathrm{~K}$. Measurements were made at these temperatures and at $4 \mathrm{~K}$ between the temperature steps.

A total of $4 \mathrm{~h}$ was required to reach the last $300-\mathrm{K}$ anneal, and the experiment, was held at this temperature overnight. Then the experiment assembly was again cooled to $4 \mathrm{~K}$ and the irradiation at $2 \mathrm{MW}$ continued for $13.5 \mathrm{~h}$. (Total time, $15 \mathrm{h.})$

At this point, the step-annealing procedure outlined above was repeated. Following the final warm-up, the experiment remained at room temperature in the sample chamber at a helium gas pressure of about 350 torr for a week or more while the radioactivity decayed.

\section{RESULTS}

The irradiation has been completed and the in situ electrical resistance results are compiled for this report. Because of the time required for radioactive decay of the experiment assembly, data for the postirradiation tests will be reported later.

The five electrical-resistivity specimens measured in situ were Nomex Aramid 410, 2850 FT epoxy, EPON 828 epoxy, Fireban 1011 glass-epoxy, and Formvar-coated wire. Each specimen except for the Formvar-wire pair had the same cross-sectional area, but a different thickness. To calculate volume resistivities on four of the specimens, a geometric form factor (area/length). was used. The product of the form factor in $\mathrm{cm}$ and the resistance in ohms is the volume resistivity in ohm-cm. The thickness of samples and form factors is given in Table I. All measurements were made at $90 \mathrm{~V}$. 
The current through the coaxial lead to the "open" specimen position was small $(<1 \mathrm{pA})$ at $4 \mathrm{~K}$, about $3 \mathrm{pA}$ at room temperature, and about $60 \mathrm{pA}$ when measured with the reactor at low power. In some cases, specimen currents were nearly as small as the current through the "open"lead. These are marked with an asterisk in the tables that follow. In all other cases, it was assumed that the leakage or stray current in any one specimen sircuit was about the same as that in the "open" circuit. The "open" circuit current value was therefore subtracted from each specimen current before calculating the resistivity. In most cases, the "open" circuit current was much less than half of any individual specimen current, and thus the resistances and resistivities given in the tables that follow could be too large by a factor of two at the most.

The initial resistivities of the specimens during cool-down before irradiation are given in Table II. Since there is no practical value for a form factor for the twisted open pair of Formvar wires, only the resistance in ohms, rather than resistivity, is given. The changes with temperature were not very uniform. The purely organic materials Nomex Aramid 410 and EPON 828 epoxy changed much more than the two materials containing inorganic filler, 2850 FT epoxy and Fireban 1011 glass-fiber epoxy. This was also true of the same materials under irradiation conditions, as will be seen in the data given below.

Measurements taken with the reactor moved into place ready for the irradiation after cool-down are given in the first row of Table III. W1th the reactor at $50 \mathrm{~W}$ and at $500 \mathrm{~W}$, the measurements were almost the same as with the reactor in place at zero power. It is to be noted that current in the "open" circuit increased from about $0.5 \mathrm{pA}$ in the initial 
measurements to about $65 \mathrm{pA}$ with the reactor in place at zero, $50 \mathrm{~W}$, and $500 \mathrm{~W}$. The radiation dose rate with the reactor in place and at these low power levels is estimated to be about $1.5 \times 10^{4} \mathrm{R} / \mathrm{h}$, or about a factor of ten higher than expected at the toroldal-field magnet coils of an operating fusion device. At the 5-KW level, all indicated resistances were about one-half their zero-power-level values, and at the 50-KW level they were about one-sixth of the values at zero power level. The resistivity values with the reactor at full power ( $2 \mathrm{MW}$ ) are given in the second row of Table III. At this power level, the radiation-dose rate is greater than $10^{7} \mathrm{R} / \mathrm{h}$, and ionization produced a current of about 1500 pA in the "open" circuit. The EPON 828 specimen carried the largest current, $6500 \mathrm{pA}$. It was possible to make measurements even though the guard-ring circuit indicated a current flow of several microamperes due to the intense ionization. It is also noted that gamma-ray heating caused the specimen chamber temperature to rise from 3.4 to $4.8 \mathrm{~K}$. After $1.5 \mathrm{~h}$ of irradiation at full power, the reactor power was reduced to zero. Current values immediately dropped by a factor of at least 10. Movement of the reactor 2 meters away yielded still lower values, which are given in the first row of Table IV. The step-annealing process was begun, and measurements at $3.4 \mathrm{~K}$ after the $100-\mathrm{K}$ anneal showed some resistance recovery; however, this may have been the result of decay of induced radioactivity in the LTIF and/or the experiment assembly during the time required for warm-up.

The experiment assembly was then allowed to warm up to room temperature overnight. Measurements made the next morning showed a decrease 
in resistance in the specimens by a factor of 2 to 50 . The "open" circuit showed a relatively large current of $30,000 \mathrm{pA}$, and the guard-ring circuits were almost shorted. The temperature in the sample chamber was $305 \mathrm{~K}$, and the pressure had not changed from 350 torr. At this point, the chamber was purged by evacuating to .06 torr and refilling with dry hellum gas to 350 torr. This procedure decreased the guard-ring current to zero, and all other currents reached reasonable values, as shown in the second row of Table IV. Measurements were again made after cool-down to $3.4 \mathrm{~K}$. These measurements, shown in the third row of Table IV, as well as the 305-K measurements, may be compared to the initial measurements at the same temperature given in Table II.

All but one of the room-temperature resistivity values measured after the 1.5-h irradiation are higher than the initial values. All of the 3.4-K resistivity values are somewhat lower.

Further irradiation at $3.4 \mathrm{~K}$ was begun by bringing the reactor power directly to $2 \mathrm{MW}$. At full power, the resistivity values were about the same as those shown in the bottom row in Table III and did not change during the course of the irradiation. After $13.5 \mathrm{~h}$, the reactor was again shut down and moved $2 \mathrm{~m}$ away. The total dose for the entire radiation time $(15 \mathrm{~h})$ was about $2 \times 10^{\circ} \mathrm{K}$, and the fast-neutron flux (> $3 \mathrm{MeV}$ ) was $3 \times 10^{13} \mathrm{n} / \mathrm{cm}^{2}$. Resistivity measurements taken $\frac{1}{2} \mathrm{~h}$ after final reactor shutdown are given in the first row of Table $V$. The same step-anneal procedure as used previously after the 1.5-h irradiation was then followed. Again there was little change until the room-temperature measurements were made. The guard-ring currents were once more found to be high, and this time the sample chamber was evacuated to .08 torr and purged with helium 
gas three times. This brought the guard-ring currents down to less than $0.5 \mu \mathrm{A}$. Resistivity measurements at room temperature taken after the purge are given in the second row of Table $V$. They are a little lower than the initial (preirradiation) room-temperature resistivity values. Additional room-temperature measurements taken after the second irradiation showed interesting results. With the reactor on, the specimen resistances were found to increase when the reactor was moved from 2 meters to a position 3. meters away from the LTIF. Also, the resistance values increased with time. The measurements in the last row of Table $\mathrm{V}$ were taken eight days after shutdown with the reactor on and $3 \mathrm{~m}$ away from the experiment. All values except one are higher than initial values.

\section{CONCLUSIONS AND FUTURE PLANS}

The initial volume resistivities of four of the insulating materials tested were on the order of $10^{14} \Omega-\mathrm{cm}$. The values obtained here may be on the low side because of 1imitations imposed by experimental conditions; i.e., long coaxial cables, small specimen size, etc.

Generally, the resistivites are larger at liquid-hellum temperature, with the pure organic specimens showing more change with temperature than the inorganic-filled specimens.

Comparison of the initial and final measurements indicates that the resistivity of these specimens was affected very little by a dose of $2 \times 10^{8} \mathrm{R}$ received at liquld-helium temperature. The volume resistivity under the influence of irradiation-dose rate of about $15,000 \mathrm{R} / \mathrm{h}$ fell. to approximately $10^{13} \Omega-\mathrm{cm}$. This is about ten times the expected gamma-dose rate at the front face of the toroidal-field magnet of a fusion device. 
Even with the BSR at full power, the resistivity did not fall below $10^{11}$ $\Omega-\mathrm{cm}$. The specimens with filler such as glass fiber underwent smaller changes in resistivity with temperature.

Warming the experiment to room temperature after irradiation at low temperature did result in some interesting changes. These phenomena could have been caused by outgassing of either experiment-construction materials or any one or more types of specimens in the irradiation container. From the temperature dependence of the effect and the fact that it disappears with a gas purge, we infer that it is caused by substances which become volatile only above $100 \mathrm{~K}$. Possibllities include water and some hydrocarbons. At present, however, this is only a hypothesis. If this interpretation proves to be correct, a helium refrigeration system for a fusion magnet system must be designed to cope with the system contamination which would occur at warmun.

In the near future, all of the specimens will be removed from the cadmium container, examined, photographed, weighed, and tested. It would be advantageous to analyze the purge gas in the system upon warm-up during the next irradiation experiment. However, tests on the postirradiation specimens must be conducted before definite plans can be made for the next irradiation experiment.

\section{ACKNOWLEDGMENTS}

The aid and suggestions of J. M. Shoopman, R. Wallace, J. Hendrix, and C. Fitzpatrick in construction of specimen molds, specimens, test equipment, and the irradiation container are very much appreciated. The 
time and effort of the group that ran the LTIF (J. M. Williams,

C. E. Klabunde, and J. K. Redman) are gratefully acknowledged. The authors wish to thank I. M. Barker for typing this report for reproduction. 
X. REPERENCES

1. Guess, J. F., Boom, R. W., Coltman, R. R., Jr., and Sekula, S. T., "A Survey of Radiation Damage Effects in Superconducting Magnet Components and Systems," Oak Ridge National Laboratory Report TM-5187, November 1975.

2. Parkinson, W. W., and Sisman, 0., "The Use of Plastics and Polymers in Nuclear Radiation," Nuc1. Eng. and Design 17, 247, 1975.

3. Klabunde, C. E., and Kelley, B. C., "Irradiation Facilities in the Oak Ridge Nalluilal Laburatory Bulk Ehiclding Reaotor," TID 4500 (CONF-660 511), May 1966.

4. American Society for Testing and Materials, 1976 Book of ASTM Standards, Part 38, ASTM Standard D 257-76, D. C. Resistance or Conductance of Insulating Materials, pp. 86-106, 1975.

5. American Society for Testing and Materials, 1975 Book of ASTM Standards, Part 40, ASTM Standard D877-67, Dielectric Breakdown of Insulating Liquids Using Disk Electrodes, pp. 168-171.

6. Charlesby, A., Atomic Radiation and Polymers, Pergamon Press, 1960.

7. Lee, H., and Neville, K., Handbook of Epoxy Resins, McGraw Hill, 1967.

8. Froelich, K. J., and F1tzpatrick, C. M., "Lap Shear Strength of Selected Adhesives in Liquid N1trogen and at Room Temperature," ORNL-TM-5658, September 1976.

9. NEMA Standards Publication, No. LI-1971, Industrial Laminated Thermosetting Products, National Electrical Manufacturers Association, New York, $19 \% 1$. 
Table I

Thickness and Form Factors of Specimens

\begin{tabular}{lcccc}
\hline & $\begin{array}{c}\text { Nomex } \\
410\end{array}$ & $\begin{array}{c}2850 \mathrm{FT} \\
\text { Epoxy }\end{array}$ & $\begin{array}{c}\text { EPON } \\
828 \text { Epoxy }\end{array}$ & $\begin{array}{c}\text { Fireban } \\
1011\end{array}$ \\
\hline $\begin{array}{c}\text { Thickness } \\
(\mu \mathrm{m})\end{array}$ & 240 & 90 & 480 & 660 \\
$\begin{array}{c}\text { Form Factor } \\
(\mathrm{cm})\end{array}$ & 13 & 35 & 6.6 & 4.8 \\
\hline
\end{tabular}

Table II

Preirradiation Measurements on Specimens

\begin{tabular}{|c|c|c|c|c|c|}
\hline & \multicolumn{3}{|c|}{ Resistivity, $\rho$} & $10^{12} \Omega-\mathrm{cm}$ & $\begin{array}{c}\mathrm{R} \\
10^{12} \Omega\end{array}$ \\
\hline $\mathrm{T} \mathrm{K}$ & $\begin{array}{c}\text { Nomex } \\
410 \\
\end{array}$ & $\begin{array}{c}2850 \mathrm{FT} \\
\text { Epoxy } \\
\end{array}$ & $\begin{array}{c}\text { EPON } 828 \\
\text { Epoxy }\end{array}$ & $\begin{array}{c}\text { Fireban } \\
1011\end{array}$ & $\begin{array}{c}\begin{array}{c}\text { Formvar } \\
\text { Wire }\end{array} \\
\end{array}$ \\
\hline 305 & 115 & 65 & 50 & 50 & 55 \\
\hline 100 & 270 & 175 & 140 & 90 & 55 \\
\hline 50 & 240 & 750 & 120 & 55 & 55 \\
\hline 3.4 & $>2000 *$ & 380 & $>1300 *$ & 80 & 40 \\
\hline
\end{tabular}

(Potential applied $=90 \mathrm{v}$.

(Reactor at 0 power, 2 m away.) 
Table III

Measurements at Low Temperature During Irradiation

\begin{tabular}{l||cccc|c||c}
\hline & \multicolumn{3}{||}{ Resistivity, $\rho$} & $10^{12} \Omega-\mathrm{cm}$ & $\begin{array}{c}\mathrm{R} \\
10^{12} \Omega\end{array}$ & $\begin{array}{c}\text { Reactor } \\
\text { Power } \\
\text { Level }\end{array}$ \\
\hline T K & $\begin{array}{c}\text { Nomex } \\
410\end{array}$ & $\begin{array}{c}2850 \mathrm{FT} \\
\text { Epoxy }\end{array}$ & $\begin{array}{c}\text { EPON 828 } \\
\text { Epoxy }\end{array}$ & $\begin{array}{c}\text { Fireban } \\
1011\end{array}$ & $\begin{array}{c}\text { Formvar } \\
\text { W1re }\end{array}$ & \\
\hline 3.4 & 13 & 45 & 14 & 60 & 1.5 & $0,50 \mathrm{~W}$ \\
4.8 & .35 & 5 & .12 & .35 & 0.11 & $2 \mathrm{MW}$ \\
\hline
\end{tabular}

Table IV

Measurements after $1.5 \mathrm{~h}$ Irradiation

\begin{tabular}{|c|c|c|c|c|c|c|}
\hline \multirow[b]{2}{*}{$\mathrm{T} K$} & \multicolumn{2}{|c|}{ Resistivity, } & \multicolumn{2}{|c|}{$10^{12} \mathrm{~s}-\mathrm{cm}$} & \multirow{2}{*}{$\frac{10^{22} \Omega}{\begin{array}{c}\mathrm{R} \\
\text { Wormvar } \\
\text { Wire }\end{array}}$} & \multirow{2}{*}{$\begin{array}{c}\text { Time } \\
\text { After } \\
\text { Reactor } \\
\text { Shut down }\end{array}$} \\
\hline & $\begin{array}{c}\text { Nomex } \\
410\end{array}$ & $\begin{array}{c}2850 \mathrm{FT} \\
\text { Epoxy }\end{array}$ & $\begin{array}{c}\text { EPON } 828 \\
\text { Epoxy }\end{array}$ & $\begin{array}{c}\text { Fireban } \\
1011\end{array}$ & & \\
\hline 3.4 & 50 & 50 & 50 & 15 & 4.5 & $1 \mathrm{~h}$ \\
\hline 305 & 160 & 55 & 55 & 65 & $150 *$ & $\begin{array}{c}\text { (purge) } \\
20 \mathrm{~h}\end{array}$ \\
\hline 3.4 & 360 & 270 & 125 & 20 & 15 & $\begin{array}{c}(\text { cool-down }) \\
24 \mathrm{~h}\end{array}$ \\
\hline
\end{tabular}


Table V

Measurements After 15 h Irradiation

\begin{tabular}{|c|c|c|c|c|c|c|}
\hline \multirow[b]{2}{*}{$\mathrm{T} \mathrm{K}$} & \multicolumn{4}{|c|}{ Resistivity, $\rho \quad 10^{12} \Omega-\mathrm{cm}$} & \multirow{2}{*}{$\begin{array}{c}\mathrm{R} \\
10^{12} \Omega \\
\begin{array}{c}\text { Formvar } \\
\text { Wire }\end{array}\end{array}$} & \multirow{2}{*}{$\begin{array}{c}\text { Time } \\
\text { After } \\
\text { Reactor } \\
\text { Shutdown }\end{array}$} \\
\hline & $\begin{array}{c}\text { Nomex } \\
410\end{array}$ & $\begin{array}{c}2850 \text { FT } \\
\text { Epoxy }\end{array}$ & $\begin{array}{c}\text { EPON } 828 \\
\text { Epoxy }\end{array}$ & $\begin{array}{c}\text { Fireban } \\
1011\end{array}$ & & \\
\hline 3.5 & 30 & 32 & 15 & 9 & 1.7 & $\frac{1}{2} h$ \\
\hline 302 & 75 & 30 & 35 & 15 & $90 *$ & $\begin{array}{c}\text { (purge) } \\
24 \mathrm{~h}\end{array}$ \\
\hline 307 & 210 & 80 & 90 & 115 & 75 & 8 days \\
\hline
\end{tabular}


ORNL-DWG 63-2214A

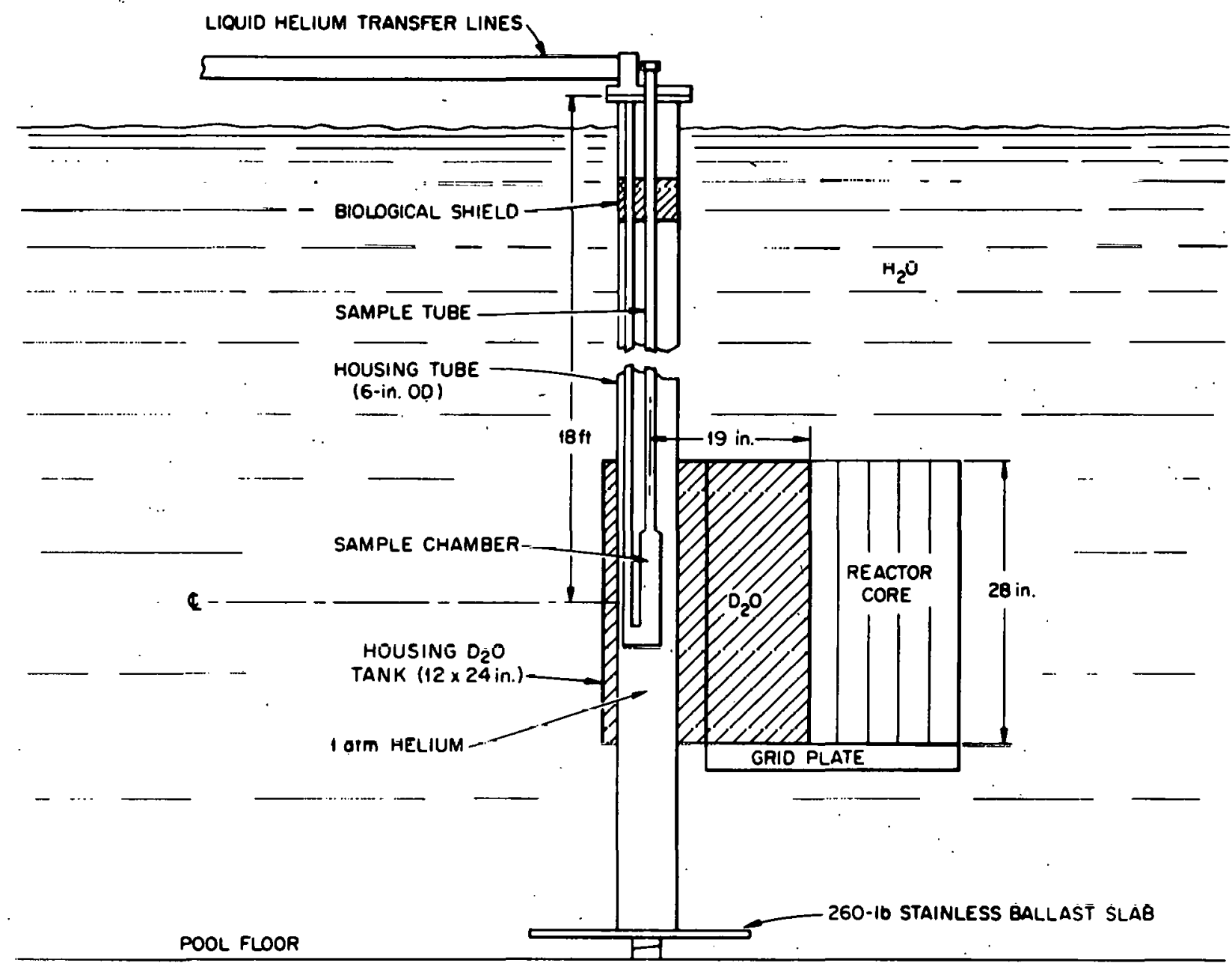

Fig. 1. Schematic side view of the Low-Temperature Irradiation Facility. 


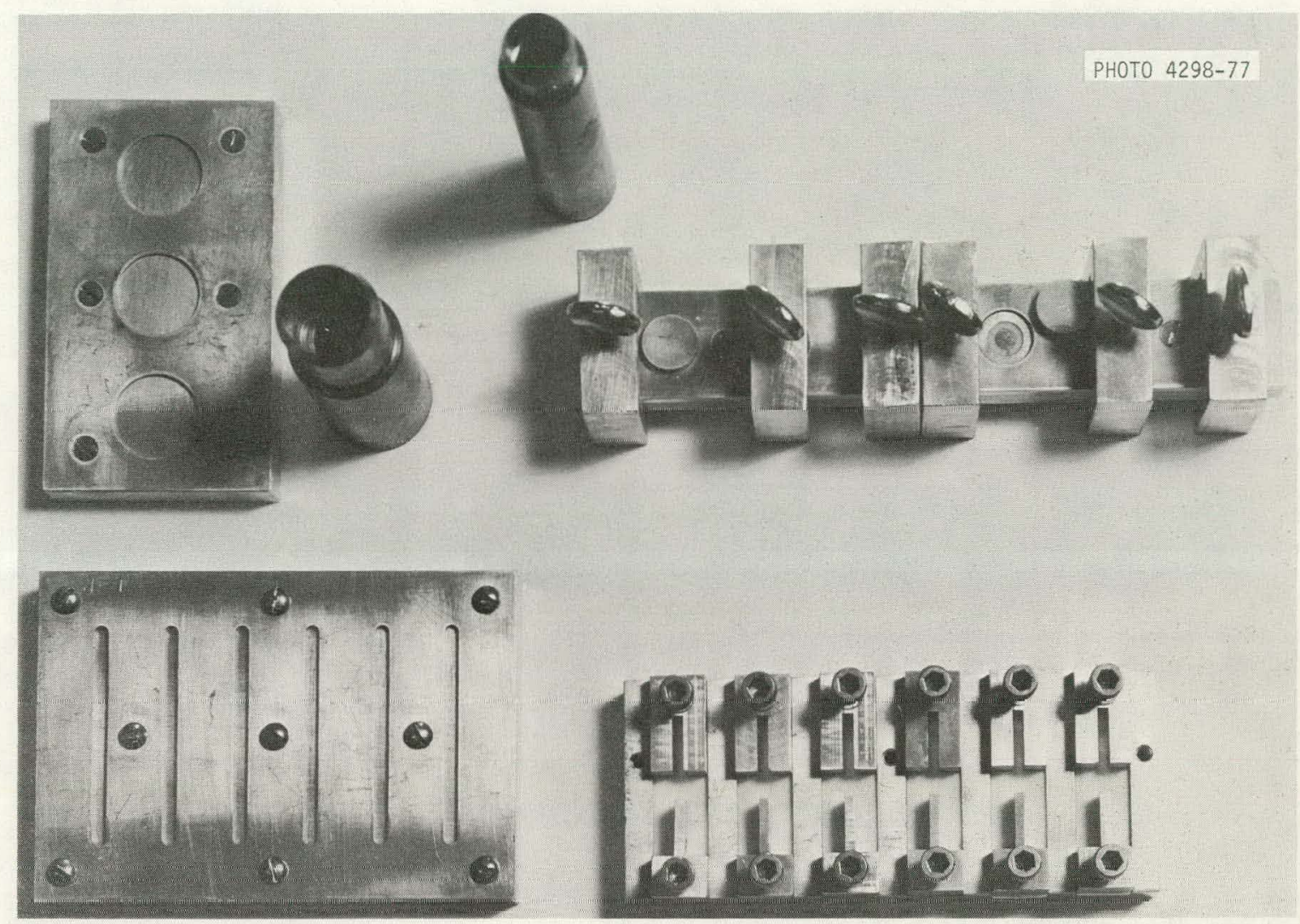

Fig. 2. Specimen fabrication molds and fixtures. 


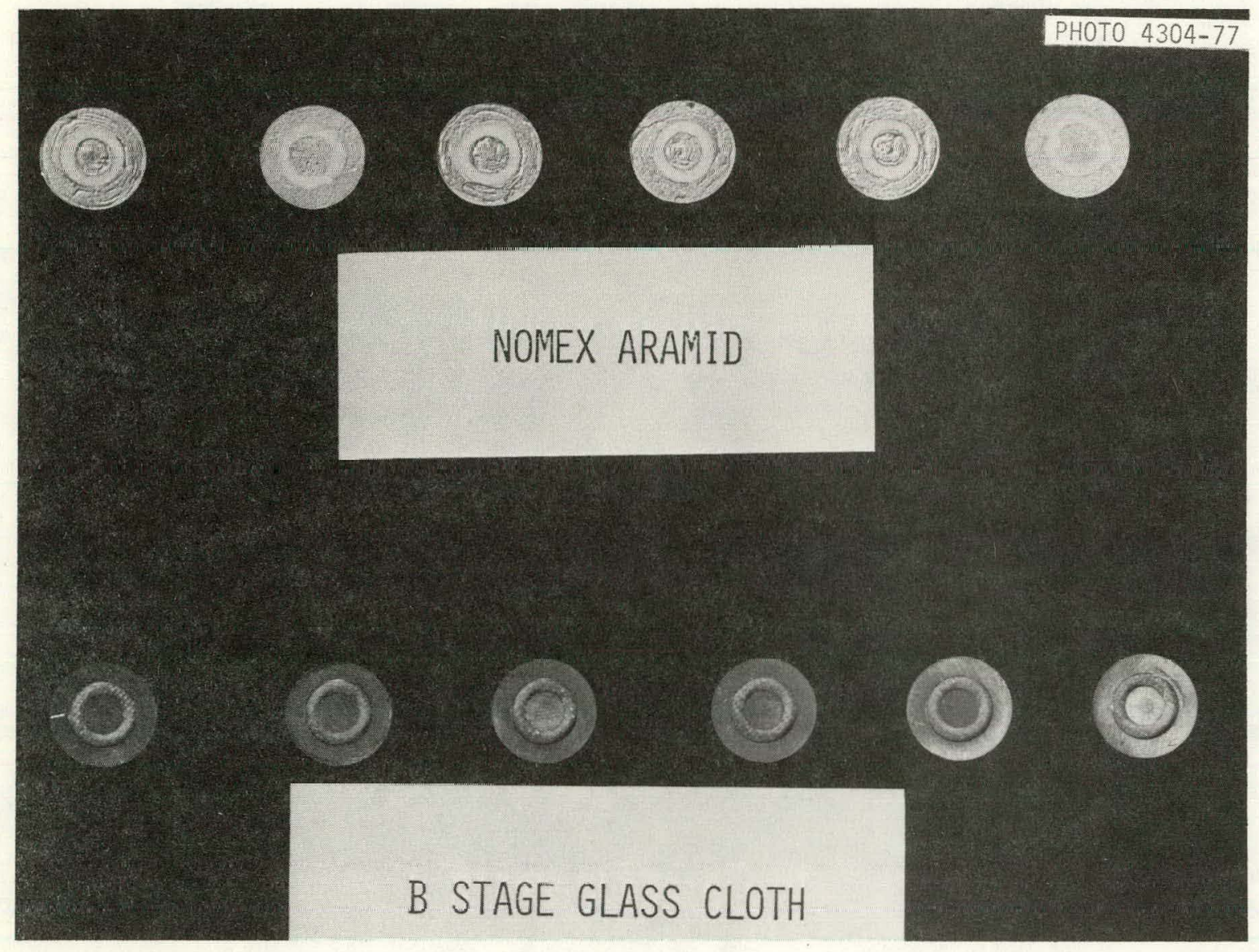

Fig. 3. Typical electrical-resistance specimens (1.25 cm diam.). 


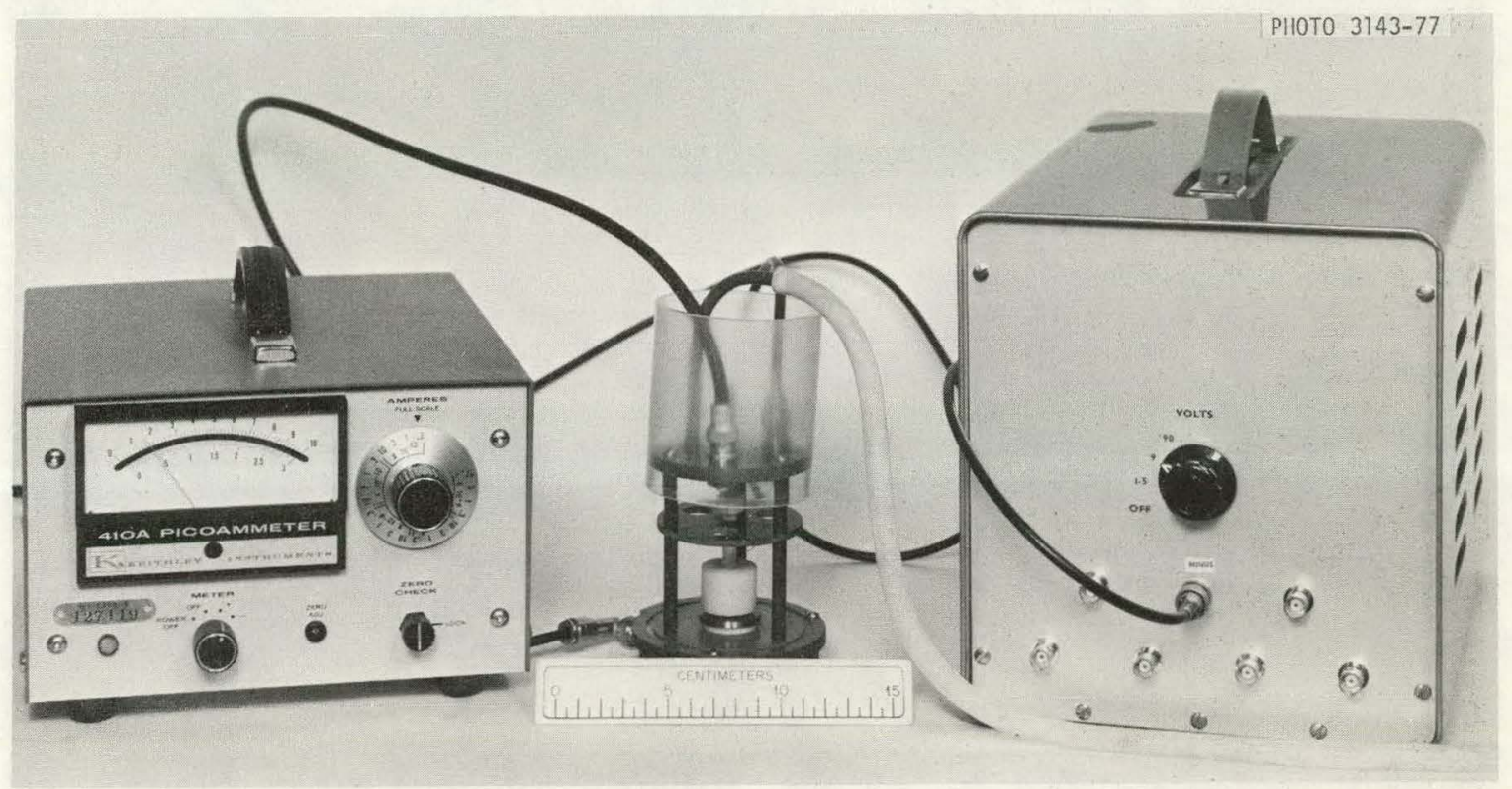

Fig. 4. Equipment for measurement of electrical resistance. 


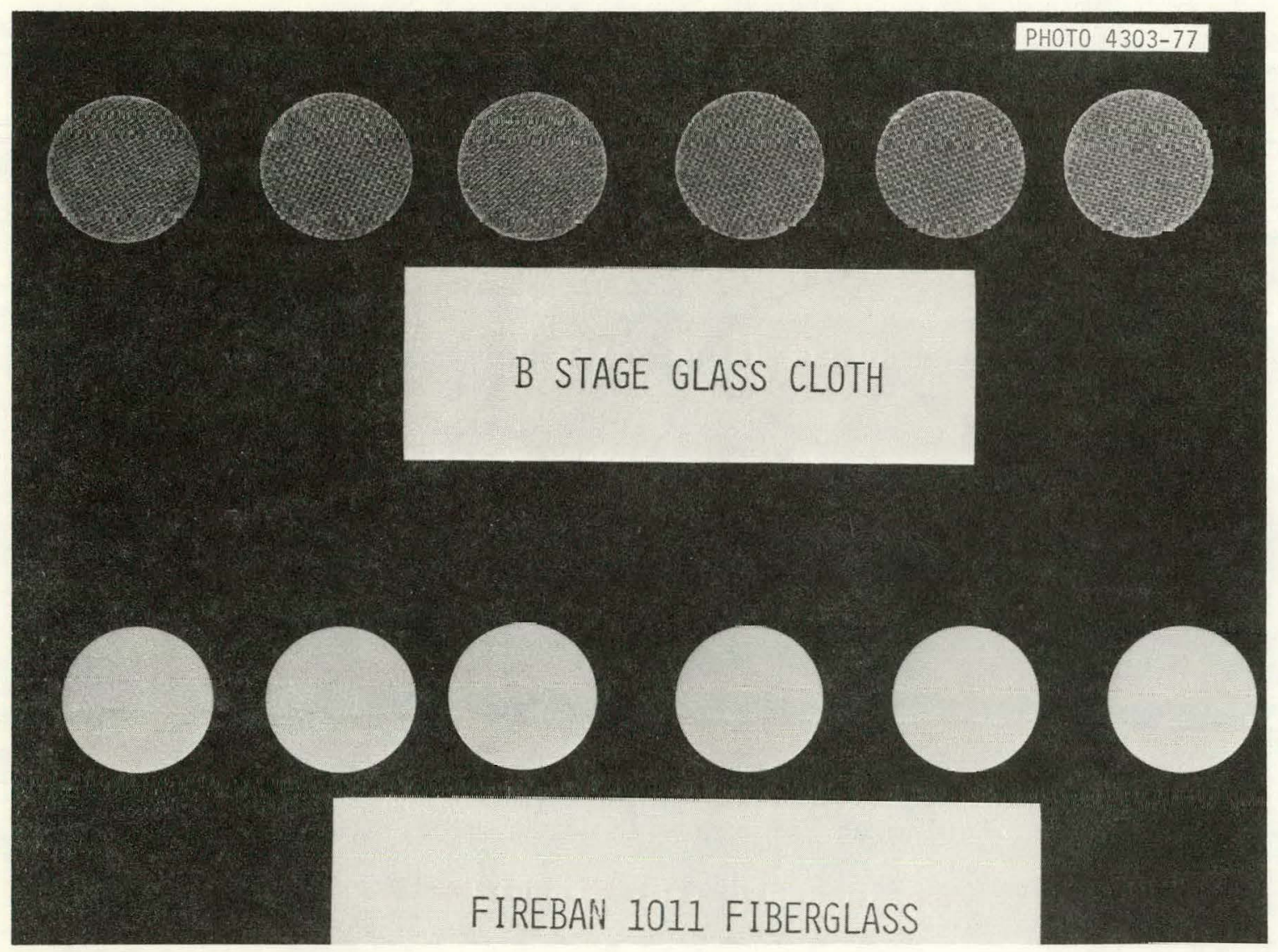

Fig. 5. Typical electrical-breakdown specimens $(1.88 \mathrm{~cm}$ diam.). 


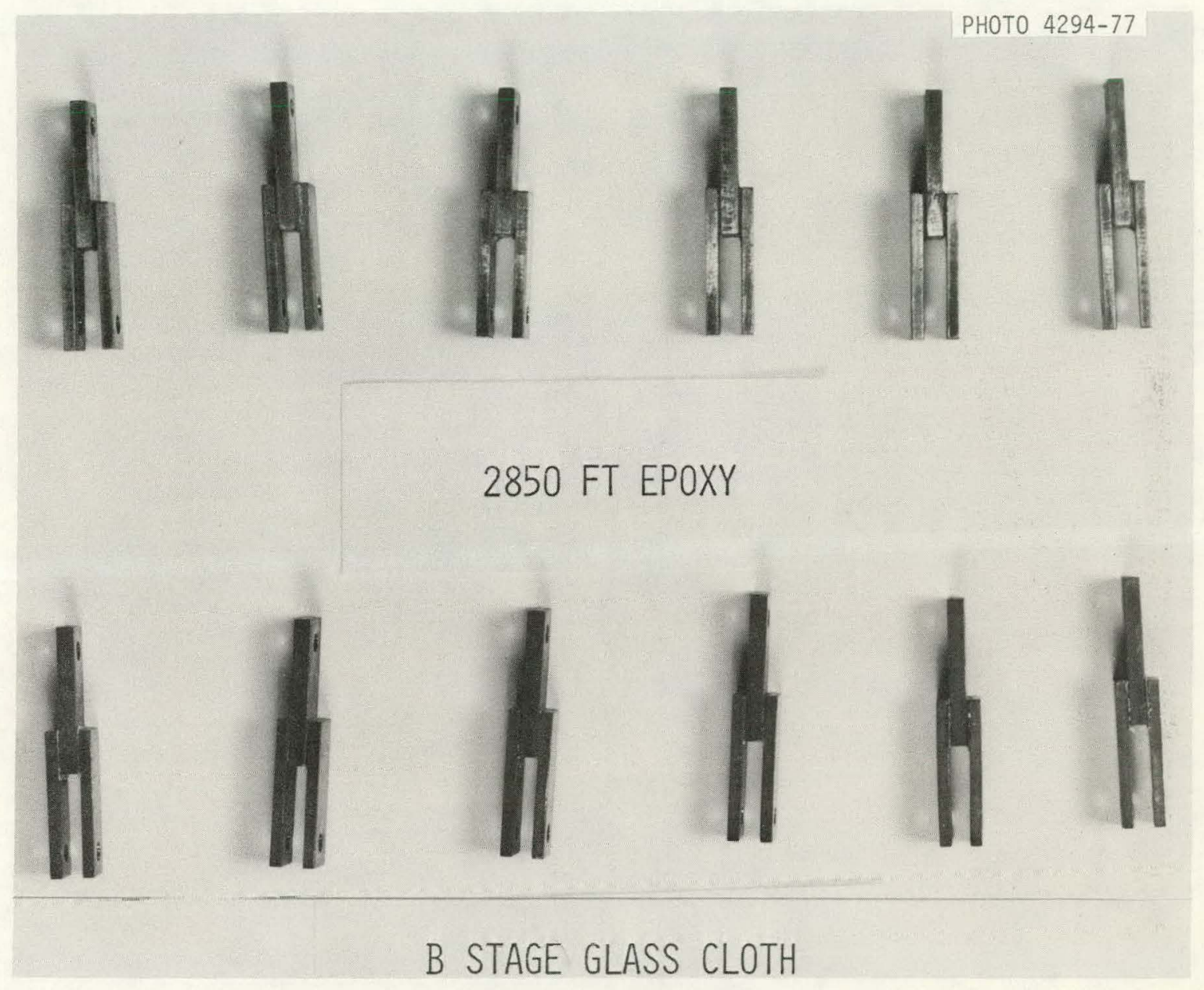

Fig. 6. Tensile shear specimens (each 3.2 cin long). 


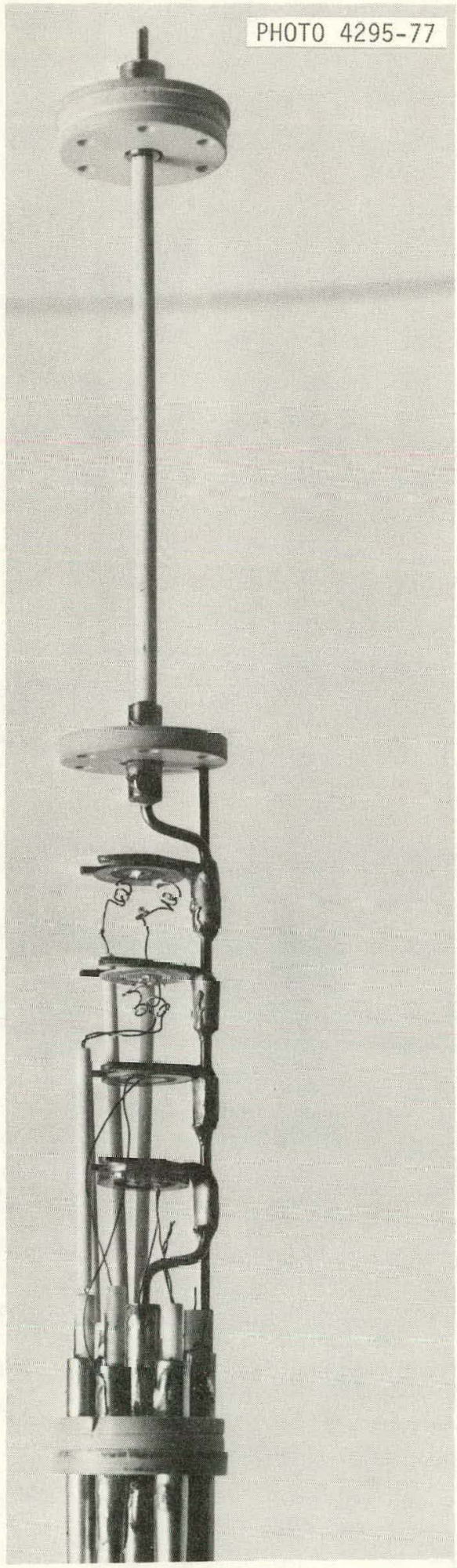

Fig. 7. Interior of specimen container with four specimens in place. 
ORNL/TM-6193

\section{INTERNAL DISTRIBUTION}

1. J. K. Ballou

2. L. A. Berry

3. R. L. Brown

4. P. B. Burn

5. D. A. Canonico

6-10. R. R. Coltman, Jr.

11. W. A. Fietz

12. C. M. Fitzpatrick

13. P. N. Haubenreich

14. G. G. Kelley

15-19. R. H. Kernohan

20. W. C. Koehler

21. C. G. Lawson

22-26. C. J. Long

27. M. S. Lube11

28. J. W. Lue

29. J. N. Luton

30. H. E. McCoy

31. J. R. Miller

32. 0. B. Morgan

33. H. Postma

34. M. Roberts

35. M. W. Rosenthal
36. R. T. Santoro

37. J. L. Scott

38. S. T. Sekula

39. T. E. Shannon

40. G. M. Slaughter

41. D. Steiner

42. W. C. T. Stoddart

43. P. B. Thompson

44. P. L. Walstrom

45. J. R. Weir

46. M. K. Wilkinson

47. J. M. Williams

48. H. T. Yeh

49. F. W. Young, Jr.

50. A. Zucker

51-52. Central Research Library

53. Document Reference Section

54-56. Laboratory Records Department

57. Laboratory Records, ORNL R.C.

58-59. Fusion Energy Division Library

60. Fusion Energy Division Reports Office

61. ORNL Patent Office

\section{EXTERNAL DISTRIBUTION}

62-88. Technical Information Center, Oak Ridge

89. Research and Technical Support Division, DOE, ORO

90. R. W. Boom, 513 Energineering Research Building, University of Wisconsin, Madison, Wisconsin 53706

91. B. S. Brown, Materials Science Division, Argonne National Laboratory, Argunine, Illinols 60439

92. J. L. Christian, General Dynamics/Convair, San Diego, California 92112

93. J. F. Clarke, DMFE, DOE, Mail Stop G-234. Washington, D.C. 20545

94. M. M. Cohen, DNFE, DOE, Mail Stop G-234, Washington, D.C. 20545

95. E. N. C. Dalder, DMFE, DOE, Mail Stop G-234, Washington, D.C. 20545

96. F. R. Fickett, National Bureau of Standards, Boulder, Colorado 80302

97. S. A. Gause, Engineering Manager, Micarta Division, Westinghouse Electric Corporation, Hampton, South Carolina 29924

98. C. D. Henning, DMFE, DOE, Maii Stop G-234, Washington, D.C. 20545

99. M. B. Kasen National Bureau of Standards, Boulder Colorado 80302

100. F. Mazandarany, Energy Systems Department, General Electric Company, Schenectady, New York 12345

101. R. P. Reed, National Bureau of Standards, Boulder, Colorado, 80302

102. L. Snead, Brookhaven National Laboratory, Upton, New York 11973

103. J. L. Young, Wegtinghouse Electric Corporation, Box 10864, Pittsburgh, Pennsylvania 15236

104. K. S. C. Young, Plasma Physics Laboratory, Box 451, Building $1 \mathrm{~K}$, Prinçeton, New Jersey 08540

105. K. M. Zwilsky, DMFE, DOE, Mall Stop G-234, Washington, D.C. 20545 